\title{
Effect of bovine colostrum on the serum insulin-like growth factor-I (IGF-I), the IGF binding proteins-2 and -3 and the thyroid hormones in weaning piglets
}

CHRISTELLE BOUDRY', JEAN-PAUL DEHOUX², FRÉDÉRIC G. COLINET ${ }^{1,3}$, JOSÉ WAVREILLE ${ }^{4}$, DANIEL PORTETELLE ${ }^{3}$, YVES BECKERS' and ANDRÉ THÉWIS'

\begin{abstract}
${ }^{1}$ Animal Science Unit, Gembloux Agro-Bio Tech, University of Liège, Gembloux, Belgium, 'Experimental Surgery Unit, Faculty of Medicine, Catholic University of Louvain, Brussels, Belgium, ${ }^{3}$ Animal and Microbial Biology Unit, Gembloux Agro-Bio Tech, University of Liège, Gembloux, Belgium, ${ }^{4}$ Animal Breeding, Quality Production and Welfare Unit, Walloon Agricultural Research Centre, Gembloux, Belgium
\end{abstract}

\section{Abstract}

This study examined the effect of a bovine colostrum supplementation on growth performance, feed intake and the hormonal response of piglets at weaning. Ninety-six newly-weaned piglets were assigned for four weeks to one of the two treatments: Control (diet with bovine milk whey) and Colostrum (diet with bovine colostrum whey) treatments. The supplements were incorporated in a commercial diet at $20 \mathrm{~g} / \mathrm{kg}$ during the first 2 weeks after weaning and lowered to $10 \mathrm{~g} / \mathrm{kg}$ for the next 2 weeks. Body weight and feed intake were measured weekly. Blood samples were taken weekly for determination of circulating IGF-I, its binding proteins and the thyroid hormones $\left(\mathrm{T}_{3}\right.$ and $\left.\mathrm{T}_{4}\right)$. During the first week of the trial, the Colostrum-fed piglets presented improved growth performance, feed intake and feed efficiency and a higher concentration in circulating IGF-I (+15\%) compared to the Control piglets. In both treatments, the circulating thyroid hormones were reduced by weaning and the levels measured at weaning were recovered earlier by the Colostrum-fed piglets compared to the Control group $(P<0.05)$. It is concluded that hormonal response observed after the bovine colostrum supplementation is, at least in part, consequent of the positive action of bovine colostrum on the feed intake.

Keywords: bovine colostrum, pigs, weaning, IGF-I, IGFBP, thyroid hormones

\section{Zusammenfassung}

\section{Die Wirkung von Rinderkolostrum auf den Serum IGF-I Faktor, die IGF Bindungsproteine -2 und -3 sowie die Thyroidhormone wachsender Schweine}

Untersucht wird der Einfluss von Rinderkolostrumgaben auf Wachstumsleistungen, Futteraufnahme und Hormonantworten bei wachsenden Schweinen. Sechsundneunzig Absetzferkel wurden zwei Gruppen zugeordnet die während vier Wochen unterschiedlich gefüttert wurden. Eine Gruppe erhielt im Aufzuchtfutter Molkenmilchpuder, das Futter der zweiten Gruppe dagegen Kolostrummolke. In den ersten zwei Versuchswochen betrug dieser Zusatz $20 \mathrm{~g} / \mathrm{kg}$ Futter und in den zwei Folgewochen $10 \mathrm{~g} / \mathrm{kg}$. Körpergewicht und Futterverbrauch wurde wöchentlich erfasst. Wöchentliche Blutproben wurden zur 
Bestimmung von IGF-I, Bindungsproteinen und Thyroidhormonen entnommen. In der ersten Versuchswoche zeigte die Kolostrumgruppe gegenüber der Kontrollgruppe ein besseres Wachstum, bessere Futteraufnahme und -verwertung sowie eine höhere IGF Konzentration (+15\%). In beiden Versuchsgruppen war der Thyroxidhormonspiegel zum Absetzzeitpunkt reduziert erholte sich jedoch bei der Kolostrumgruppe signifikant schneller. Es wird geschlussfolgert, dass die beobachtete Hormonantwort nach einem Rinderkolostrumzusatz auf eine Verbesserung der Futteraufnahme hinweist.

Schlüsselwörter: Rinderkolostrum, Schwein, Absetzferkel, IGF-I, IGFBP,

Thyroxidhormone

\section{Introduction}

Colostrum is the milk produced by a mammal for the first 24 to $96 \mathrm{~h}$ postpartum. More than a rich source of essential nutrients, colostrum is also bringing biologically active components to the new-born which are essential for specific functions. The most important bioactive components in colostrum include:

- growth factors (insulin-like growth factors, transforming growth factors and epidermal growth factors) which promote the growth and development of the new-born and

- antimicrobial factors (lactoferrin, lysozyme, lactoperoxidase and immunoglobulins) which provide passive immunity and protection against infections during the first weeks of life (BLUM and BAUMRUCKER 2008).

Several authors have shown that weanling pigs fed with a bovine colostrum supplemented diet presented better growth performance, feed intake and feed efficiency than piglets receiving the same diet without colostrum (see BOUDRY et al. 2008 for a review). However, mechanisms by which the bovine colostrum exerts its effects are currently unknown. Several studies investigated the effect of bovine colostrum on the gastro-intestinal tract (HUGUET et al. 2006 and 2007, KING et al. 2007 and 2008) and the immune system (BOUDRY et al. 2007) of the newly-weaned piglets but very few information was found about the effect on the endocrinal system (HUGUET et al. 2006 and LE HUEROU-LURON et al. 2003).

Insulin like growth factor-I (IGF-I) is a very potent mitogenic growth factor that has been shown to affect proliferation and differentiation of a wide variety of cell types (BEE et al. 2007). In vivo IGF-I is bound to one of six high affinity IGF binding proteins (IGFBPs). The IGFBPs prolong the circulating half-life of IGF, transport IGF from the extracellular space into tissues and localize IGF to specific cell types and tissues (COHICK 1998). IGFBP-2 and -3 account for the majority of circulating IGFBPs activity in growing pigs (COLEMAN and ETHERTON 1991). IGFBP-2 has a higher affinity for IGF-II and inhibits IGF action by preventing the binding of IGF to IGF receptors while IGFBP-3 has a similar affinity for IGF-I and -II and potentiates the action of IGF (RAJARAM et al. 1997). The thyroid hormones (3.5.3'-triiodothyronine, $\mathrm{T}_{3}$; and thyroxine, $\mathrm{T}_{4}$ ) are metabolic hormones which may modulate IGF-I levels (BUONOMO and BAILE 1991).

Blood concentrations of IGF-I, $\mathrm{T}_{3}$ and $\mathrm{T}_{4}$ are reported to respond proportionally to feeding level (CARROLL et al. 1998, HATHAWAY et al. 2003, SAGGAU et al. 2000). 
Considering the effect of bovine colostrum on feed intake and growth performance and the implication of IGF-I in growth and the influence of nutritional status on IGF-I, IGFBP-2 and -3 and the thyroid hormones, was investigated in the present study the effects of bovine colostrum supplementation on these hormones in newly-weaned piglets.

\section{Materials and methods}

The experimental protocol used in this study has been reviewed and approved by the Animal Care and Use Committee (protocol No. 02/05) of Gembloux Agro-Bio Tech (University of Liège) in accordance with the EC Directive 86/609/ECC for Animal Experiments.

\section{Animals}

Ninety-six Belgian Piétrain $\times$ (Large White $\times$ Landrace) piglets weaned at $26 \pm 2$ days of age with an average BW of $8.3 \pm 0.8 \mathrm{~kg}$ were selected from 15 litters (Animal Breeding, Quality Production and Welfare Unit, Walloon Agricultural Research Centre, Gembloux, Belgium).

\section{Treatments}

Two treatments were compared:

- a control diet (commercial diet with bovine milk whey powder) and

- a colostrum diet (commercial diet with bovine colostrum whey powder).

The commercial diet (SCAR, Herve, Belgium) was a starter diet free of any growth promoters. This commercial diet was distributed the week before weaning to the 15 litters from which the piglets were selected for the trial. The two supplements were mixed with the commercial diet at a rate of $20 \mathrm{~g} / \mathrm{kg}$ for the first 2 weeks of the trial and $10 \mathrm{~g} / \mathrm{kg}$ for the next 2 weeks. Compositions of the experimental diets are given in Table 1. The bovine colostrum whey used in this study was prepared from bovine colostrum standardised at $75 \mathrm{~g}$ of lg per litre (Centre d'Economie Rurale, Marloie, Belgium). This colostrum was defatted by centrifugation. Whey was obtained after rennet coagulation at $37^{\circ} \mathrm{C}$ for $24 \mathrm{~h}$ and separation from curds by a mechanical press. The whey was then freeze-dried. The milk whey used was a commercial spray-dried powder (Euroserum, Port-sur-Soane, France). All pigs had ad libitum access to a four-hole feeding through and a nipple drinker.

\section{Experimental design}

The animals were blocked according to BW and gender and assigned to one of the two treatments. For each treatment, the piglets were housed in four pens of 12 piglets ( 6 males, 6 females). Piglets from the same litters were distributed between the two treatments.

BW and feed consumption were evaluated weekly to determine the average daily gain $(A D G)$, the average daily feed intake (ADFI) and the feed efficiency (G/F) which is obtained by the ratio: BW gain/feed intake. Piglets were weighed in the early morning without feed or water restriction. 
Table 1

Centesimal and chemical compositions of the Control and Colostrum diets

Futtermittel und chemische Zusammensetzung für die Kontroll- und Kolostrumgruppen

\begin{tabular}{lcccc}
\hline & \multicolumn{2}{c}{ Control diets } & \multicolumn{2}{c}{ Colostrum diets } \\
& $20 \mathrm{~g} / \mathrm{kg}$ & $10 \mathrm{~g} / \mathrm{kg}$ & $20 \mathrm{~g} / \mathrm{kg}$ & $10 \mathrm{~g} / \mathrm{kg}$ \\
\hline Ingredients, g/kg feed & & & & \\
Barley & 247 & 249.5 & 247 & 249.5 \\
Wheat & 189 & 191 & 189 & 191 \\
Soybean meal, 49\% CP & 175.5 & 177 & 175.5 & 177 \\
Nutribig premix & 147 & 148.5 & 147 & 148.5 \\
Maize & 98 & 99 & 98 & 99 \\
Heat treated maize & 49 & 49.5 & 49 & 49.5 \\
Toasted Soybeans & 41.5 & 42 & 41.5 & 42 \\
Chicory pulp & 24.5 & 24.2 & 24.5 & 24.2 \\
Soybean oil & 5 & 5 & 5 & 5 \\
Synthetic amino acids and minerals & 4.5 & 4.5 & 4.5 & 4.5 \\
Milk whey powder & 20 & 10 & 0 & 0 \\
Colostrum whey powder & 0 & 0 & 20 & 10 \\
Chemical composition, g/kg dry matter & & & & \\
Dry matter, g/kg feed & 869 & 871 & 867 & 870 \\
Crude protein & 182 & 183 & 194 & 189 \\
Ether extract & 35 & 34 & 34 & 34 \\
Crude fiber & 36 & 36 & 36 & 36 \\
Starch & 365 & 385 & 377 & 381 \\
Ash & 60 & 60 & 60 & 60 \\
Lysine & 9.7 & 9.3 & 10.1 & 9.3 \\
\hline
\end{tabular}

aThe premix (Roche Vitamins, Deinze, Belgium) is composed by $60 \%$ of milk products, $12 \%$ of oleaginous seeds, $10 \%$ of cereal seeds by-products, $5 \%$ of tuber and roots by-products and $12 \%$ of minerals and vitamins (vitamins, minerals and amino acids supplied per kilogram of premix: vitamin A, $100000 \mathrm{IU}$; vitamin D3, 13000 IU; vitamin $\mathrm{E}$, $335 \mathrm{mg}$; vitamin $\mathrm{K} 3,9 \mathrm{mg}$; vitamin B1, $13 \mathrm{mg}$; vitamin B2, $34 \mathrm{mg}$; vitamin B3, $100 \mathrm{mg}$; vitamin B6, $20 \mathrm{mg}$; vitamin C, $302 \mathrm{mg}$, vitamin PP, $200 \mathrm{mg}$; folic acid, $2 \mathrm{mg}$; choline, $2163 \mathrm{mg}$; iron (as FeSO $)$ ) 1,332 mg; copper (as CuSO ), 1100 mg; manganese (as $\mathrm{MnSO}_{4}$ ), $400 \mathrm{mg}$; cobalt (as CoSO$\left.)_{4}\right), 7 \mathrm{mg}$; zinc (as $\mathrm{ZnSO}_{4}$ ), 1583 mg; iodine (as Cal $0_{6}$ ), 14 mg; selenium (as $\mathrm{Na}_{2} \mathrm{SeO}_{4}$ ), 3 mg; Ca, 39586 mg; P, 8584 mg; Na, 8100 mg; L-lysine HCl, 16240 mg; DL-methionine, 6630 mg; L-threonine, 2990 mg; L-tryptophan, 260 mg; lysine, 22740 mg; methionine, 8994 mg; threonine, 10217 mg; tryptophan, 2352 mg). ${ }^{b}$ Providing the following per kilogram of the complete diet (g): methionine, 0.25 ; lysine, 0.5 ; threonine, 0.5 ; tryptophan, 0.25 ; monocalcique phosphate, 3

\section{Diet and whey analyses}

The diets distributed during the trial were ground to pass a $1 \mathrm{~mm}$ screen (Cyclotec 1.093, Foss Tecator AB) before dry matter, ether extract, Kjeldahl N, crude fibre and ash analyses (AOAC 1990) were conducted. Samples from the 4 diets were also ground to pass a $0.5 \mathrm{~mm}$ screen for analyse of lysine (AccQ-Tag, Waters, Milford, MS, USA) and starch (adapted from FAISANT et al. 1995). The same analyses were performed on milk and bovine colostrum wheys. Additional analyses were conducted on both milk and colostrum wheys. IGF-I, IGF-II and insulin concentrations were determined with sandwich ELISA quantitation kits (Diagnostics Systems Laboratories, Assendelft, The Netherlands) according to the manufacturer's procedure. Total $\lg G$ and lactoferrin concentrations were measured by Sandwich ELISA (Bethyl laboratories, Montgomery, TX, USA) and reverse-phase HPLC (Shodex Asahipak C4P$504 \mathrm{D}$ column), respectively. The results of the analysis on the experimental diets and the wheys are presented in Tables 1 and 2, respectively. 
Table 2

Chemical composition of the milk and colostrum wheys

Chemische Zusammensetzung der Milch- und Kolostrummolke

\begin{tabular}{lcc}
\hline Composition, g/kg dry matter & Milk whey & Colostrum whey \\
\hline Dry matter, g/kg powder & 923 & 956 \\
Crude protein & 84 & 627 \\
Ether extract & 15 & 10 \\
Ash & 120 & 105 \\
Lysine & 4.9 & 43.4 \\
IgG & 2 & 496 \\
Lactoferrin & $<0.1$ & 10.6 \\
IGF-I & $33 \mathrm{ng} / \mathrm{g}$ & $2500 \mathrm{ng} / \mathrm{g}$ \\
IGF-II & $12 \mathrm{ng} / \mathrm{g}$ & $25 \mathrm{ng} / \mathrm{g}$ \\
Insulin & $<1 \mathrm{ng} / \mathrm{g}$ & $<1 \mathrm{ng} / \mathrm{g}$ \\
\hline
\end{tabular}

\section{Blood collection}

Blood samples from the jugular vein were collected into dry tubes (Ref 368430, Becton Dickinson Benelux S.A., Erembodegem, Belgium). The day of weaning (day 0), blood was collected from one piglet of each litter. These animals were then excluded from the experiment. On days 7 and 21, half of the experimental piglets in each pen were blood sampled. The other half was sampled on the days 14 and 28 . This method of sampling was used to minimise the effect of blood sampling on measured parameters.

Blood serum was separated by centrifugation at $1000 \times \mathrm{g}$ for $15 \mathrm{~min}$ at $4^{\circ} \mathrm{C}$ and then stored at $-20^{\circ} \mathrm{C}$ until analysis.

\section{Hormone determination}

$\mathrm{T}_{3}$ and $\mathrm{T}_{4}$ concentrations were determined in blood serum by RIA kits (DSL-3100 ACTIVE and DSL-3200 ACTIVE respectively, Diagnostic Systems Laboratories, Assendelft, The Netherlands) according to the manufacturer's procedure based on the presence of specific antibodies adhered to the internal surface of propylene tubes.

IGF-I was determined by RIA according to a method described by RENAVILLE et al. (1996). In this method, a cryoprecipitation step is used to eliminate aggregated proteins in the serum. Briefly, after acid-ethanol extraction ( $87.5 \%$ ethanol and $\left.12.5 \% \mathrm{HCl} \mathrm{mol} \mathrm{I}^{-1} \mathrm{v} / \mathrm{v}\right)$, an aliquot of the supernatant was neutralized with $0.855 \mathrm{~mol}^{\text {Tris }}$ base $\mathrm{I}^{-1}$ at a ratio of 5:2. The samples were stored at $-20^{\circ} \mathrm{C}$ overnight and then centrifuged at $3000 \times \mathrm{g}$ for $60 \mathrm{~min}$ at $4^{\circ} \mathrm{C}$. The supernatant was decanted into fresh test tubes and used in the RIA. The minimum detectable dose of IGF-I was $1 \mathrm{ng} . \mathrm{ml}^{-1}$. Intra and inter-assay coefficients of variation were $12 \%$ and $16 \%$ respectively, for the low standard concentration $(2.5 \mathrm{ng} / \mathrm{mL})$ and $6.5 \%$ and $9 \%$, respectively, for the high standard concentration $(250 \mathrm{ng} / \mathrm{mL})$.

Western ligand blotting was performed to evaluate serum IGFBP-2 and -3 concentrations according to a semi-quantitative method described in RENAVILLE et al. (1996). In short, $1 \mu \mathrm{l}$ of SDS-denatured serum was applied to a $4 \%$ stacking gel and electrophoresis was performed through a $12.5 \%$ polyacrylamide gel. Prestained protein ladder (SM0671, Fermentas, Hanover, MD) was run in parallel lanes. The gels were then soaked in Towbin buffer (2.5 
mmol Tris $\mathrm{I}^{-1}, 192 \mathrm{mmol}$ glycine $\mathrm{I}^{-1}, 20 \%(\mathrm{v} / \mathrm{v})$ methanol, $\left.\mathrm{pH} 8,3\right)$ and proteins were blotted onto nitrocellulose sheets (Hybond-C Extra, Amersham Biosciences, UK). Electrophoresis and electrotransfer were performed using the Mini-protean II system (Bio-Rad, Richmond, CA, USA). After saturation, membranes were incubated with ${ }^{125}$-labelled rhIGF-I (see below iodination procedure; $4000 \mathrm{cpm} \mathrm{cm}^{-2}$ blot) overnight at $4^{\circ} \mathrm{C}$. The membrane were then washed, air-dried and exposed to Kodak BioMax XAR films (Eastman Kodak Company, Rochester, NY, USA) for 15 days at $-70^{\circ} \mathrm{C}$. Autoradiograms were scanned and band intensities were analysed with Imagemaster 1D Prime (GE Healthcare, Diegem, Belgium). A serum pool was used as internal standard. Band intensity of the samples is expressed relatively to the intensity measured for the standard (\% of standard).

\section{lodination procedure}

Recombinant IGF (rhIGF-I, GroPep Limited, Adelaide, Australia) was used as iodinated trace and as RIA standard. The hormone was labeled with ${ }^{125}$ I-Na using the lactoperoxidase method. ${ }^{125}$ I-labeled rhIGF-I was separated from iodine using a Centricon Centrifugal Filter Devices with YM-3 membranes (Millipore Corporation, Bedford, MA, USA). The specific activity was $80 \mu \mathrm{Ci} \mu \mathrm{g}^{-1}$.

\section{Statistical analyses}

For the performance and feed intake data, there were four repeated measures. For the blood parameters analysis was separated in two groups of piglets with two replicates for each (day 7 and day 21 for the first half of the piglets and day 14 and day 28 for the second half of the piglets). Modelling of repeated records was done using the MIXED procedure of SAS (SAS Inst., Inc., Cary, NC, USA). Analysis of variance tested treatment (Control-Colostrum) by time (days post-weaning) interactions. Bodyweight at weaning of each piglet was added as covariable in the model for the blood parameters. Effects were compared using the CONTRAST statement in the repeated MIXED analysis. The pen was used as the experimental unit for ADFI and G/F. For all the other parameters, the animal was used as experimental unit.

Pearson Correlation coefficients were determined (CORR procedure) between the growth performances and the blood hormonal concentrations.

To evaluate the effect of weaning on the blood parameters, hormonal concentrations measured during our trial from day 7 to day 28 post-weaning were compared to the values recorded on naïve piglets on day 0 by Dunnett's test.

The values presented are Ismeans \pm standard error (treatment $\times$ time). The differences were declared significant at $P<0.05$.

\section{Results}

\section{Growth performance}

The ADG, ADFI and G/F for the 4-week trial are presented in Table 3. The ADG was higher for the colostrum whey supplemented pigs compared to the Control piglets $(P<0.001)$ during the first week of the trial. The next 3 weeks, the ADG were similar. Finally, the ADG calculated on the total experimental period was higher for the piglets supplemented with bovine 
colostrum whey $(P=0.02)$. The ADFI and $G / F$ per pen $(n=4)$ were greater during the first week of the trial for pigs fed the Colostrum treatment compared to that of pigs fed the Control $\operatorname{diet}$ (respectively $P=0.03$ and $P=0.04$ ). For the next 3 weeks and the entire 4-week trial, feed consumption and $\mathrm{G} / \mathrm{F}$ were not affected by the experimental diet.

Table 3

Body weight (BW), average daily gain (ADG), average daily feed intake (ADFI) and feed efficiency (G/F) of piglets fed a commercial diet containing milk (Control) or bovine colostrum whey (Colostrum) for 4 weeks

Körpergewicht, tägliche Zunahme, Futteraufnahme und -verwertung in den vier Versuchswochen

\begin{tabular}{|c|c|c|c|c|}
\hline \multirow[b]{2}{*}{ Measurements and days } & \multicolumn{4}{|c|}{ Treatments } \\
\hline & Control & Colostrum & Standard error & Significance \\
\hline \multicolumn{5}{|l|}{ BW, kg (n=48) } \\
\hline 0 & 8.34 & 8.33 & 0.19 & ns \\
\hline 7 & 8.89 & 9.51 & 0.24 & * \\
\hline 14 & 11.0 & 11.5 & 0.29 & ns \\
\hline 21 & 14.0 & 14.5 & 0.35 & ns \\
\hline 28 & 17.6 & 18.4 & 0.45 & ns \\
\hline Significance & \multicolumn{4}{|c|}{ Time $\times$ Treatment $^{* * *}$, Time $^{* * *}$, Treatment ${ }^{\text {ns }}$} \\
\hline \multicolumn{5}{|l|}{$A D G, g /$ day $(n=48)$} \\
\hline 0 to 7 & 81 & 170 & 15.6 & $* * *$ \\
\hline 7 to 14 & 297 & 280 & 14.4 & ns \\
\hline 14 to 21 & 430 & 434 & 17.6 & ns \\
\hline 21 to 28 & 516 & 548 & 18.9 & ns \\
\hline 0 to 28 & 330 & 361 & 11.3 & * \\
\hline Significance & \multicolumn{4}{|c|}{ Time $\times$ Treatment ${ }^{* * *}$, Time ${ }^{* * *}$, Treatment* } \\
\hline \multicolumn{5}{|l|}{ ADFI, $g /$ day $(n=4)$} \\
\hline 0 to 7 & 256 & 346 & 38.5 & * \\
\hline 7 to 14 & 497 & 495 & 35.8 & ns \\
\hline 14 to 21 & 791 & 822 & 46.5 & ns \\
\hline 21 to 28 & 974 & 992 & 76.2 & ns \\
\hline 0 to 28 & 623 & 665 & 43.2 & ns \\
\hline Significance & \multicolumn{4}{|c|}{ Time $\times$ Treatment $^{* * *}$, Time $^{* * *}$, Treatment ${ }^{\text {ns }}$} \\
\hline \multicolumn{5}{|l|}{$G / F, g / g(n=4)$} \\
\hline 0 to 7 & 0.31 & 0.48 & 0.078 & * \\
\hline 7 to 14 & 0.56 & 0.61 & 0.023 & ns \\
\hline 14 to 21 & 0.55 & 0.52 & 0.038 & ns \\
\hline 21 to 28 & 0.56 & 0.54 & 0.032 & ns \\
\hline 0 to 28 & 0.53 & 0.54 & 0.029 & ns \\
\hline Significance & \multicolumn{4}{|c|}{ Time $\times$ Treatment $^{\mathrm{ns}}$, Time $^{* * *}{ }^{*}$ Treatment $^{\text {ns }}$} \\
\hline
\end{tabular}

${ }^{*} P<0.05,{ }^{* * *} P<0.001$, ns not significant $(P>0.05)$

\section{Hormonal concentrations}

Figures 1, 2 and 3 represent the evolution of serum IGF-I, $T_{3}$ and $T_{4}$ concentrations during the trial. A line on each graphic represents the mean concentration measured at weaning.

IGF-I

On day 7 of the trial, the circulating IGF-I concentrations were increased by $15 \%$ in the Colostrum-fed piglets compared to the Control treatment $(P<0.05)$. However, the levels of 
circulating IGF-I recorded in both treatments remained similar over all the trial to the mean concentration measured the day of weaning on littermates $(P>0.05)$.

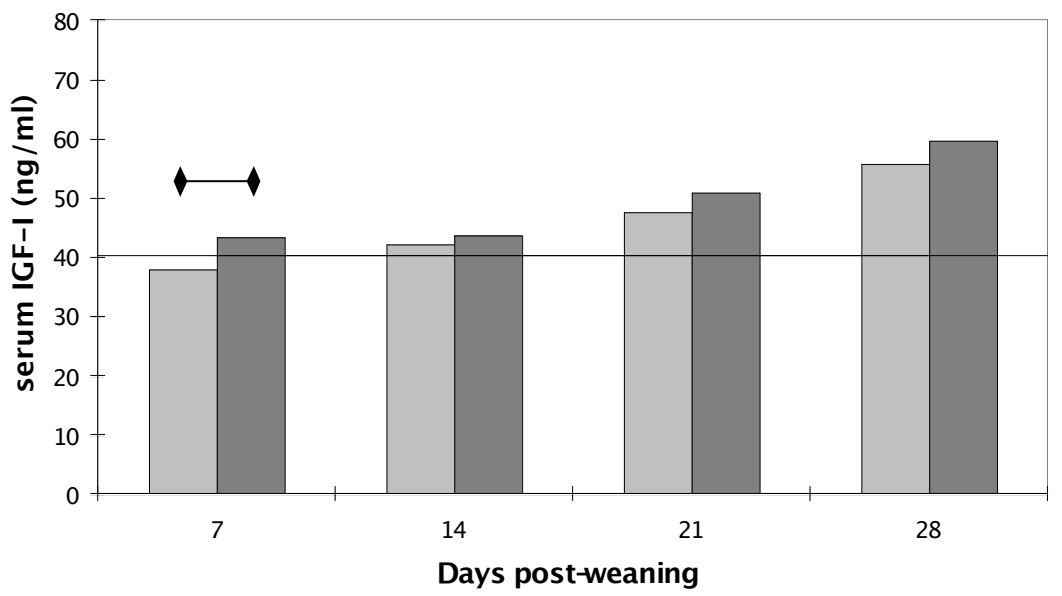

$\square$ Control $\square$ Colostrum - Day 0

The horizontal line represents the mean IGF-I concentration in littermates the day of weaning $(40.2 \pm 8.7 \mathrm{ng} / \mathrm{ml}, \mathrm{n}=15)$ $\longrightarrow$ : on the same day, mean concentrations of the two treatments are different, $P<0.05)$.

Figure 1

IGF-I concentrations in the blood serum of newly-weaned piglets fed a commercial diet containing milk (Control, $n=24$ ) or bovine colostrum whey (Colostrum, $n=24$ ) for 4 weeks

IGF-I Konzentration im Blutserum

IGFBP-2 and -3

No effect of the colostrum supplementation was observed on IGFBP-2 and -3 levels during our trial except on day 21 with a reduction of the IGFBP-2 concentration in the colostrum-fed piglets $(P<0.01)$ (data not shown). Like for IGF-I, no effect of weaning was observed on the binding proteins (IGFBP-2 and $-3, P>0.05)$.

$T_{3}$ and $T_{4}$

The bovine colostrum supplementation had an effect on the thyroid response, with a higher level of circulating $T_{4}$ on day 14 of the trial for the colostrum-fed piglets compared to the Control treatment. The thyroid response was also influenced by weaning. It reduced temporarily $(P<0.05)$ the levels of $\mathrm{T}_{3}$ and $\mathrm{T}_{4}$ in both groups of piglets compared to the mean concentration measured the day of weaning on littermates. For $\mathrm{T}_{3^{\prime}}$ a decrease was only observed in the Control group on day 7 while for $T_{4}$ the initial level was recovered on day 21 for the Colostrum group and on day 28 for the Control group. 


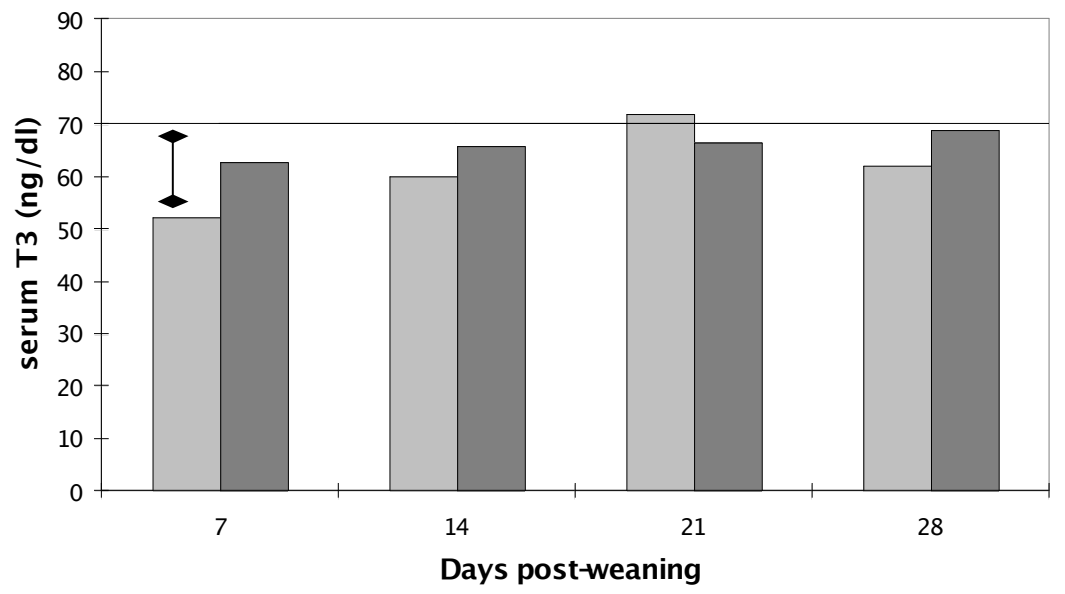

$\square$ Control $\square$ Colostrum - Day 0

The horizontal line represents the mean $T_{3}$ concentration in littermates the day of weaning $(70.2 \pm 13.7 \mathrm{ng} / \mathrm{dl}, \mathrm{n}=15)$ ( $I:$ the concentration of the treated piglets is different of the mean concentration measured the day of weaning, $P<0.05)$.

Figure 2

$\mathrm{T}_{3}$ concentrations in the blood serum of newly-weaned piglets fed a commercial diet containing milk (Control, $\mathrm{n}=24$ ) or bovine colostrum whey (Colostrum, $\mathrm{n}=24)$ for 4 weeks.

Thyroxidkonzentration $\left(T_{3}\right)$ im Blutserum

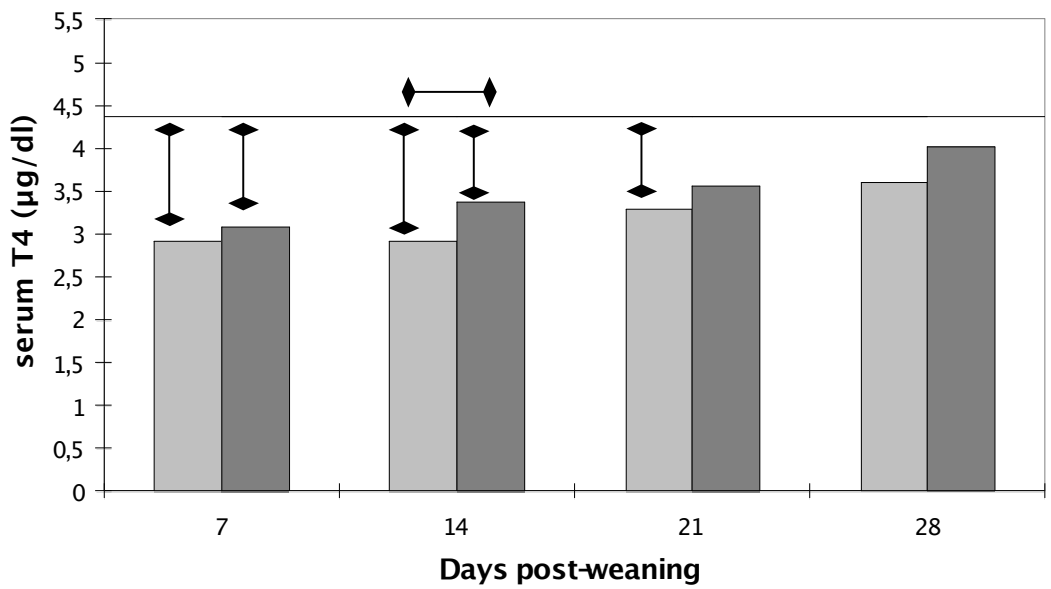

$\square$ Control $\square$ Colostrum - Day 0

The horizontal line represents the mean $\mathrm{T}_{4}$ concentration in littermates the day of weaning $(4.36 \pm 1.0 \mu \mathrm{g} / \mathrm{dl}, \mathrm{n}=15)$ $\checkmark$ : on the same day, mean concentrations of the two treatments are different, $P<0.05$. I: the concentration of the treated piglets is different of the mean concentration measured the day of weaning, $P<0.05$ ).

Figure 3

$\mathrm{T}_{4}$ concentrations in the blood serum of newly-weaned piglets fed a commercial diet containing milk (Control, $\mathrm{n}=24$ ) or bovine colostrum whey (Colostrum, $\mathrm{n}=24)$ for 4 weeks.

Thyroxidkonzentration $\left(T_{4}\right)$ im Blutserum 


\section{Correlations}

A positive correlation was established between circulating IGF-I concentrations and BW $(r=0.50, P<0.0001)$ and between IGF-I and ADG $(r=0.55, P<0.0001)$. For IGFBP-3 the correlations with BW and ADG are 0.46 and 0.49 , respectively $(P<0.0001)$, but no correlation between growth of the piglets and IGFBP-2 was observed. Finally, thyroid hormones $T_{3}$ and $\mathrm{T}_{4}$ are correlated with BW $(0.17(P<0.05)$ and $0.27(P<0.001)$, respectively) and ADG (both 0.26, $P<0.001)$.

\section{Discussion}

The inclusion of bovine colostrum whey in the weaning diet improved growth performance, feed intake and feed efficiency (respectively by 100, 30 and $50 \%$ ) the first week after weaning compared to the control piglets. These results agree with literature (see BOUDRY et al. 2008 for a review).

Concomitantly with the increase in growth performance and feed consumption, an increase in serum IGF-I was observed during the first week post-weaning. Insulin-like growth factor-I is a potent growth factor that has been associated with a wide range of anabolic processes. It has been shown to stimulate proliferation, differentiation and numerous other cellular functions in many different tissues (SIMMEN et al. 1998, RENAVILLE et al. 2002). Consequently, IGF-I is believed to be important in the regulation of growth and development (OWENS et al. 1999, DONOVAN et al. 2004, NEBDAL et al. 2000). The positive correlation between circulating IGF-I and the growth rate of our piglets confirms this.

CARROLL et al. (1998) showed a decrease in piglet serum IGF-I levels the first days after weaning. They associated this reduction in IGF-I with the underfeeding at weaning since BUONOMO and BAILE (1991) observed that fasting induces a decrease of blood IGF-I levels in pigs. In fact, CLEMMONS and UNDERWOOD (1991) showed that the nutritional status exerts a direct influence on circulating IGF-I, with blood IGF-I being closely related to the energy intake. Thus, during the first week of our experiment, the increase of serum IGF-I in the colostrum treatment is at least partly explained by the higher feed ingestion reported for this treatment over the same period.

Only two studies on bovine colostrum supplementation in newly-weaned piglet diet with measure of circulating IGF-I and controlled ingestion were found. LE HUEROU-LURON et al. (2003), showed an increase in circulating IGF-I for colostrum-fed piglets weaned at 7 days of age. While HUGUET et al. (2006) didn't highlight any effect of bovine colostrum on the ADG and the plasma IGF-I concentrations in 21 day-old weaned piglets. In this last study, the same amount of feed was distributed to the control and colostrum-fed piglets but unexpectedly the consumption of colostrum-fed piglets was lower than for the control piglets. From these results, it seems that bovine colostrum may induce an increase of circulating IGF-I independently of the feed consumption, however, a new study, with limited feed ingestion, is necessary to confirm this.

Like reported by others (ELFSTRAND et al. 2002), we measured a high level of IGF-I in the bovine colostrum powder used in the present study $(2500 \mathrm{ng} / \mathrm{g})$. Considering the homology between the bovine and porcine IGF-I amino acid sequence (TAVAKKOL et al. 1988), one explanation for the increased circulating IGF-I level in the colostrum-fed piglets would be 
the assimilation of colostral IGF-I. However, according to findings of others (DE RODAS 1995, DONOVAN 1997), this suggestion was dismissed. First of all, even if the content in IGF-l in bovine colostrum is very high compared to the other feedstuffs of the piglet diet, our colostrumfed piglets received approximately $2 \mu \mathrm{g}$ of IGF-I/ $\mathrm{kg}$ of BW per day during the first week post-weaning. This concentration was probably too low to increase significantly circulating IGF-I as DE RODAS et al. (1995) observed no effects on circulating IGF-I by administrating 8 $\mu \mathrm{g}$ of IGF-I/kg BW per day to 26 day-old weaned piglets. Moreover, DONOVAN et al. (1997) showed that orally administered IGF-I does not contribute significantly to circulating IGF-I concentrations of the neonatal piglet.

Even if the colostral IGF-I were probably not absorbed and had a limited systemic effect, it is likely that they had a local action within the intestine. MORGAN et al. (1996) demonstrated the presence of IGF-I receptors throughout the 28 day-old weaned piglet intestine. The colostral IGF-I may thus exert their biological function in the intestine of the weaned piglet, e.g. gut growth and development (expression of brushborder enzymes) (MORGAN et al. 1996). In their studies, HUGUET et al. (2006 and 2007) and KING et al. (2007 and 2008) reported a beneficial effect of bovine colostrum on the intestinal mucosa integrity. These effects on the intestinal structure may increase the nutrient intake and perhaps partly explain the higher feed efficiency observed in the Colostrum treatment.

Another growth factor present in bovine colostrum which is implicated in circulating IGF-I is the $\mathrm{GH}$. Treatment of growing pig with this hormone was reported to elevate serum IGF-I and IGFBP-3 and depress IGFBP-2 concentrations (ETHERTON 2004). We didn't measure the level of $\mathrm{GH}$ in the bovine colostrum powders used in the present studies but according to SCAMMEL (2001), it is very low $(<1 \mu \mathrm{g} / \mathrm{I})$, meaning that our colostrum-fed piglets received less than $1 \mathrm{ng}$ of $\mathrm{GH} / \mathrm{kg}$ BW per day during the first week of the present study. The lowest levels found in the literature with an effect on circulating IGF-I is $35 \mu \mathrm{g} / \mathrm{kg}$ of BW per day to growing pigs (about $60 \mathrm{~kg}$ ) (COLEMAN et al. 1994). Moreover, according to DUNSHEA et al. (1999) and RYBARCZYK et al. (2007), the response to $\mathrm{GH}$ is much lower in young piglets.

The fact that IGF-I/IGFBP complexes account for virtually all the circulating IGF-I in growing pigs, suggests that the increase in serum IGF-I is due in part to the effect of bovine colostrum on serum IGFBPs. However, in the present study, the effects of bovine colostrum observed on the IGF-I during the first week of the trial were not observed on their binding proteins. It is possible that changes in IGF-I levels are detected earlier than changes in IGFBP-2 and -3 because the IGF-I RIA is more sensitive than the 125I-IGF ligand blots used to detect IGFBP-2 and -3 (HATHAWAY et al. 2003). The reduction in IGFBP-2 levels on day 21 for the best growing group (colostrum treatment) is in accordance with the results of NEBDAL et al. (2000) who showed in a transgenic mouse model that IGFBP-2 is a potent inhibitor of skeletal muscle growth.

The circulating thyroid hormones $\left(\mathrm{T}_{3}\right.$ and $\left.\mathrm{T}_{4}\right)$ were decreased by weaning in our trial. This may be due to the low feed intake the first week post-weaning as SAGGAU et al. (2000) and WIECEK et al. (2010) showed that a period of limited feed supply is paralleled by a low level of thyroid hormones. This permits the body to spare energy by reducing basal metabolic rate (HORNICK et al.2000). Pre-weaning levels of $\mathrm{T}_{3}$ and $\mathrm{T}_{4}$ are recovered respectively 1 and 3 weeks after weaning for the colostrum-fed piglets while in the control diets they are recovered after 2 weeks for $T_{3}$ and 4 weeks for $T_{4}$. Thus, it is possible that bovine colostrum, by inducing 
a higher feed intake, allowed a faster recovery of $\mathrm{T}_{3}$ and $\mathrm{T}_{4}$ circulating concentrations than the Control treatment. The delayed response of $\mathrm{T}_{4}$ may be explained by a lower and slower response of this hormone to nutritional changes compared to $\mathrm{T}_{3}$ (BUONOMO and BAILE 1991).

The decrease in thyroid hormones may contribute to the reduction of circulating IGF-I levels as they exert permissive actions on IGF-I synthesis and receptor binding. They stimulate IGF-I synthesis in the liver and potentiate the effects of GH and IGF-I synthesis (RAJARAM et al. 1997).

From this study, we may conclude that the physiological effects of bovine colostrum supplementation on the hormonal response of the newly weaned piglet are, at least in part, consequent of the positive action of bovine colostrum on feed intake and can be one of the explanations (with the better feed efficiency) of the higher growth performance.

\section{Practical implications for animal nutrition}

The results of this study demonstrate that bovine colostrum has a high growth promoting activity during the first days post-weaning: its introduction in the diet at a level of $2 \%$ induces significant increases in food intake and growth performance of the piglets. This observation is really of great importance for pig producers as many problems are still associated to weaning in the modern pig husbandry, such as growth depression and occurrence of diarrhea (VAN BEERS-SCHREURS and BRUININX 2002).

\section{Acknowledgements}

The research was subsidized by the General Direction of Agriculture, Natural Ressources and Environnement (DGARNE) of the Walloon Region, Namur, Belgium.

\section{References}

Association of official analytical chemists (AOAC) (1990) Official methods of analysis. 15th ed. AOAC, Arlington, VA, USA

Bee G, Pursel VG, Mitchel AD, Maruyama K, Wells KD, Slomon MB, Wall RJ, Coleman ME, Schwartz RJ (2007) Carcass composition and skeletal muscle morphology of swine expressing an insulin-like growth factor I transgene. Arch Tierz 50, 501-19

Blum JW, Baumrucker CR (2008) Insulin-Like Growth Factors (IGFs), IGF Binding Proteins, and Other Endocrine Factors in Milk: Role in the Newborn. In: Bösze Z (ed.) Bioactive Components of Milk. New York, NY: Springer Science + Business Media Inc. 397-422

Boudry C, Buldgen A, Portetelle D, Collard A, Théwis A, Dehoux JP (2007) Effects of oral supplementation with bovine colostrum on the immune system of weaned piglets. Res Vet Sci 83, 91-101

Boudry C, Dehoux JP, Portetelle D, Buldgen A (2008) Bovine colostrum as a natural growth promoter for newly-weaned piglets: a review. Biotechnol Agron Soc Environ 12, 157-70

Buonomo FC, Baile CA (1991) Influence of nutritional deprivation on insulin-like growth factor I, somatotropin, and metabolic hormones in swine. J Anim Sci 69, 755-60

Carroll JA, Veum TL, Matteri RL (1998) Endocrine responses to weaning and changes in post-weaning diet in the young pig. Domest Anim Endocrinol 15, 183-94

Clemmons DR, Underwood LE (1991) Nutritional regulation of IGF-I and IGF-binding proteins. Am Rev Nutr $11,393-412$

Cohick WS (1998) Role of insulin-like growth factors and their binding proteins in lactation. J Dairy Sci 81, 1769-77 
Coleman ME, Etherton TD (1991) Effects of exogenous porcine growth hormone on serum insulin-like growth factor-binding proteins in growing pigs. J Endocrinol 128, 175-80

Coleman ME, Russell L, Etherton TD (1994) Porcine somatotropin (pST) increases IGF-I mRNA abundance in liver and subcutaneous adipose tissue but not in skeletal muscle of growing pigs. J Anim Sci 72, 918-24

De Rodas BZ, Sohn KS, Maxwell CV, Spicer LJ (1995) Plasma protein for pigs weaned at 19 to 24 days of age: effect on performance and plasma insulin-like growth factor-I, growth hormone, insulin, and glucose concentrations. J Anim Sci 73, 3657-65

Donovan SM, Chao JCJ, Zijlstra RT, Odle J (1997) Orally administered iodinated recombinant human insulinlike growth factor-I (125I-rhIGF-I) is poorly absorbed by the newborn piglet. J Ped Gastroenterol Nutr 24, 174-82

Donovan SM, Hartke JL, Monaco MH, Wheeler MB (2004) Insulin-like growth factor-I and piglet intestinal development. J Dairy Sci 87, E47-E54

Dunshea FR, King RH, Owens PC, Walton PE (1999) Moderate doses of porcine somatotropin do not increase plasma insulin-like growth factor-I (IGF-I) or IGF binding protein-3. Domest Anim Endocrinol 16, 149-57

Elfstrand L, Lindmark-Mansson H, Paulsson M, Nyberg L, Akesson B (2002) Immunoglobulins, growth factors and growth hormone in bovine colostrum and the effects of processing. Int Dairy J 12, 879-87

Etherton TD (2004) Somatotropic function: the somatomedin hypothesis revisited. J Anim Sci 82, E239-E224

Faisant N, Planchot V, Kozlowski F, Pacouret M-P, Colonna P, Champ M (1995) Resistant starch determination adapted to products containing high level of resistant starch. Sciences des Aliments 15, 83-9

Hathaway MR, Dayton WR, White ME (2003) Effects of antimicrobials and weaning on porcine serum insulinlike growth factor binding protein levels. J Anim Sci 81, 1456-63

Hornick JL, Van eenaeme C, Gerard O, Dufrasne I, Istasse L (2000) Mechanisms of reduced and compensatory growth. Domest Anim Endocrinol 19, 121-32

Huguet A, Sève B, Le Dividich J, Le Huërou-Luron I (2006) Effects of a bovine colostrum-supplemented diet on some gut parameters in weaned piglets. Reprod Nutr Dev 46, 167-78

Huguet A, Le Normand L, Fauquant J, Kaeffer B, Le Huërou-Luron I (2007) Influence of bovine colostrum on restoration of intestinal mucosa in weaned piglets. Livest Sci 108, 20-2

King MR, Morel PCH, Revell DK, Pluske JR, Birtles MJ (2008) Dietary bovine colostrum increases villus height and decreases small intestine weight in early-weaned pigs. Asian-Aust J Anim Sci 21, 567-73

King MR, Wester TJ, Morel PCH (2007) The effect of dietary spray-dried bovine colostrum and plasma on the response of pigs to enterotoxigenic $E$. coli challenge after weaning. Livest Sci 108, 292-4

Le Huërou-Luron I, Marion J, Bebin K, Thomas F, Ganier P, Thibault JN, Le Dividich J (2003) Supplementation of a weaning diet with a bovine colostrum extract minimizes post-weaning duodenal structural, but not functional, alterations in 7-d-old piglets. In proceedings of the 9th International Symposium on Digestive Physiology in pigs, Banff, AB, Canada 2, 238-40

Morgan CJ, Coutts AGP, McFadyen MC, King TP, Kelly D (1996) Characterization of IGF-I receptors in the porcine small intestine during postnatal development. J Nutr Biochem 7, 339-47

Nebdal S, Zink N, Lahm H, Hoeflich A, Wolf E (2000) Functional dissection of the insulin-like growth factor (IGF) system - prospects for animal breeding. Arch Tierz 43, 223-30

Owens PC, Gatford KL, Walton PE, Morley W, Campbell RG (1999) The relationship between endogenous insulin-like growth factors and growth in pigs. J Anim Sci 77, 2098-103

Rajaram S, Baylink DJ, Mohan S (1997) Insulin-like growth factor-binding proteins in serum and other biological fluids: regulation and functions. Endocr Rev 18, 801-31

Renaville R, Hammadi M, Portetelle D (2002) Role of the somatotropic axis in the mammalian metabolism. Domest Anim Endocrinol 23, 351-60

Renaville R, Massart S, Sneyers M, Falaki M, Gengler N, Burny A, Portetelle D (1996) Dissociation of increases in plasma insulin-like growth factor I and testosterone during the onset of puberty in bulls. J Reprod Fertil $106,79-86$ 
Rybarczyk A, Kmiec M, Karamucki T (2007) Association of growth hormone (GH) gene polymorphism with carcass and meat quality traits in PIC hybrid pigs. Arch Tierz 50 Special Issue, 205-13

Saggau E, Beyer M, Klein M, Schadereit R, Derno M, Jentsch W, Scholze H (2000) Effects of dietary protein quality on energy metabolism and thyroid hormone status in growing pigs. Arch Tierz 43, 633-47

Scammell AW (2001) Production and uses of bovine colostrum. Aust J Dairy Techno 56, 74-82

Simmen FA, Badinga L, Green ML, Kwak I, Song S, Simmen RCM (1998) The porcine insulin-like growth factor system: at the interface of nutrition, growth and reproduction. J Nutr 128, 315S-20S.

Tavakkol A, Simmen RCM, Simmen FA (1988) Porcine insulin-like growth factor-I (pIGF-l) Complementary deoxyribonucleic acid cloning and uterine expression of messenger ribonucleic acid encoding evolutionaily conserved IGF-I peptides. Mol Endocrinol 2, 674-81

Van Beers-Schreurs HMG, Bruininx EMAM (2002) Nutritional management to prevent disorders in postweaning pig health. In Nutrition and health of the gastrointestinal tract (ed. MC Block, HA Vahl, L de Lange, AE van de Braak, G Hemke and M Hessing), pp 135-58. Wageningen Academic publishers, Wageningen, The Netherlands

Wiecek J, Rekiel A, Skomial J (2010) Effect of feeding level and linseed oil on some metabolic and hormonal parameters and on fatty acid profile of meat and fat in growing pigs. Arch Tierz 53, 37-49

Received 15 February 2010, accepted 13 October 2010.

Corresponding author:

CHRISTELLE BOUDRY

email: christelle.boudry@ulg.ac.be

Animal Science Unit, Gembloux Agro-Bio Tech, University of Liège, Passage des Déportés 2, B-5030 Gembloux, Belgium 